
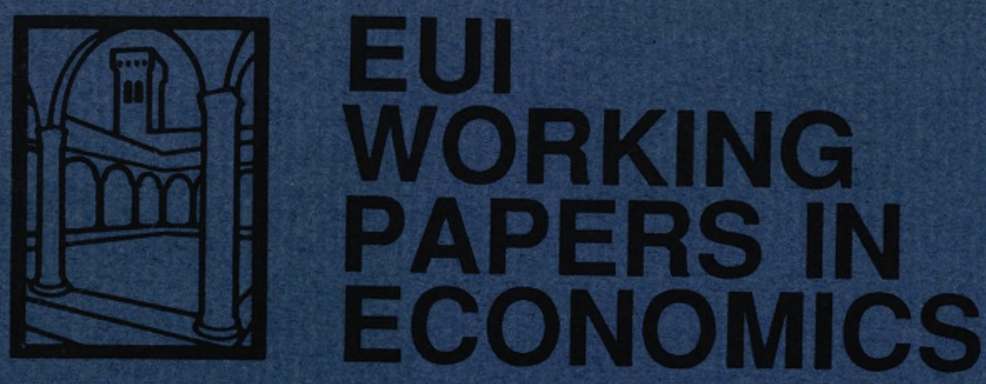

EUI Working Paper ECO No. 90/27

Implausible Results or Implausible Data?

Anomalies in the Construction of Value Added Data and Implications for Estimates of Price-Cost Markups

ROBERT J. WALDMANN 
EUI-BIB

\section{Please note}

As from January 1990 the EUI Working Paper Series is divided into six sub-series, each sub-series will be numbered individually (e.g. EUI Working Paper LAW No. 90/1). 


\section{EUROPEAN UNIVERSITY INSTITUTE, FLORENCE}

ECONOMICS DEPARTMENT

EUI Working Paper ECO No. 90/27

Implausible Results or Implausible Data?

Anomalies in the Construction of Value Added Data and Implications for Estimates of Price-Cost Markups

ROBERT J. WALDMANN

BADIA FIESOLANA, SAN DOMENICO (FI) 
All rights reserved.

No part of this paper may be reproduced in any form without permission of the author.

(c) Robert J. Waldmann

Printed in Italy in December 1990

European University Institute

Badia Fiesolana

I-50016 San Domenico (FI)

Italy 


\title{
IMPLAUSIBLE RESULTS OR IMPLAUSIBLE DATA ? \\ Anomalies in the Construction of Value Added Data and Implications for Estimates of Price-Cost Markups
}

\author{
Robert J. Waldmann \\ European University Institute
}

November 1990

\begin{abstract}
In "The Relationship Between Price and Marginal Cost in U.S. Industry," Robert Hall argues that firms in many U.S. industries charge prices higher than marginal cost. He uses a new and controversial method to measure marginal cost comparing the covariance of value added and of labour input with instruments for aggregate demand.

The pattern of markups estimated by Hall casts doubt on the validity of this approach. He estimates high markups in unconcentrated non-manufacturing industries as well as in concentrated industries. Reassuringly, the implausible pattern of estimated markups is caused by unreliable methods used to measure value added in most non-manufacturing industries. These data are inappropriate for Hall's purpose, since they contain measurement errors negatively correlated with one of Hall's instruments -- the price of oil. This biases up Hall's estimates causing the disturbing pattern.

This trivial explanation of the anomalous results reported by Hall relieve doubts about his approach and increase confidence in the evidence for markups reported by Hall and other economists. Unfortunately the unreliability of data on value added by most non-manufacturing industries makes it much more difficult to investigate the determinants of the ratio of price to marginal cost.
\end{abstract}

I would like to thank Elisabetta Addis, Brad De Long and Larry Katz for helpful discussions. 


\section{I.. INTRODUCTION}

Robert Hall's article "The Relationship Between Price and Marginal Cost in U.S. Industry" (Hall, 1988) argued that many American industries charge prices well above marginal costs, suggesting either that firms fail to maximize profits or that the possession of substantial market power by firms is the rule rather than the exception in the United States. Hall found price exceeding marginal cost not only in manufacturing--where high concentration and the plausible existence of important economies of scale suggest the importance of market power--but in relatively unconcentrated nonmanufacturing industries as well.

Subsequent research has confirmed Hall's claim that price exceeds marginal cost in United States manufacturing industries. Domowitz, Hubbard, and Petersen (1988) applied Hall's method to a more detailed and complete manufacturing data set and were able to reject the hypothesis that price

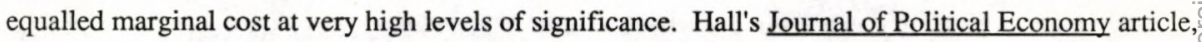
however, also analyzes non-manufacturing industries that fall outside of Domowitz, Hubbard, and Petersen's data set. Since theories of the causes of markups can be tested more easily with a larger sample of industries, and since further work to uncover the determinants and welfare effects of the market power apparently possessed by United States firms would benefit from as complete coverage of industries as possible, Hall's finding that price exceeds marginal cost outside as well as inside manufacturing remains of substantial interest.

The pattern of markups outside of manufacturing reported by Hall is somewhat surprising. Hall's regressions find that the highly competitive retail and wholesale trade industries exhibit some of the strongest evidence for markups above marginal cost. The relatively unconcentrated petroleum and coal products industry--which also sells an undifferentiated product--also exhibits high markups over marginal cost. On the other hand, Hall finds only very weak evidence against the hypothesis that the highly-concentrated and product-differentiated automobile industry is competitive, even though during the bulk of the post-war period covered by his data set foreign competition in automobiles was not an issue.

It is hard to believe that Hall's highest point estimates of markups--in petroleum and coal 
products, wholesale trade, and communications-- accurately measure the possession of substantial market power by firms in these firms. A critic of Hall might argue that this pattern of estimated markups indicates that something is seriously amiss with Hall's methodology. Measures of the markup are presented as estimates of the degree of market power possessed by firms, yet the markup estimates are not highly correlated with standard estimates of market power.

This, a critic might argue, means that Hall's markup estimates are detecting not market power but something else. The surprising pattern of non-manufacturing markups in Hall's paper thus might cast into doubt not only Hall's Journal of Political Economy results but also the conclusions of Domowitz, Hubbard, and Peterse. Since Domowitz, Hubbard, and Petersen use Hall's methodology, and since Hall's methodology appears to falsely detect market power outside of manufacturing, what warrant do we have for thinking that the interpretation of high estimated markups within manufacturing industry as revealing market power is valid? In order to credit the finding of high market power within manufacturing, we must first understand why Hall's procedure suggests this unusual pattern of substantial market power outside of manufacturing as well.

I argue in this note that the unusual pattern of markups is caused by the procedures used by the Bureau of Economic Analysis to estimate real value added in non-manufacturing industries. The pattern of estimated markups outside the manufacturing sector appears to be due to errors in measurement induced by the data construction procedures used. Data on value added in petroleum ănd coal products, wholesale trade, communication, and transportation are calculated by procedures that render them useless for Hall's purposes. The defects in the construction of the data used by Hall bias his estimates of the ratio of marginal cost to price in those industries downward. Hall rejects the hypothesis that price equals marginal cost with more confidence and finds lower ratio of marginal cost to price for the suspect industries than for others. And the hypothesis that Hall's instruments are valid can be rejected for most of the suspect industries.

The fact that the pattern of markups found by Hall is induced by his use of inappropriate data reinforces our confidence in Hall's, and in Domowitz, Hubbard, and Petersen's, conclusions and methods for manufacturing industries, since the data for manufacturing are appropriate for Hall's 
purposes. Unfortunately, the data problems mean that the only non-manufacturing industry for which appropriate data are available is the utilities industry; efforts to identify the causes of high markups are therefore restricted to a relatively small data base.

\section{HALL'S PROCEDURE AND HIS DATA}

\section{Hall's Insight}

Hall's idea was that when firms charge prices above marginal cost, the value of the output produced by a marginal worker is greater than his wage. Total factor productivity calculations are made assuming that factors are paid their marginal products, and so if price exceeds marginal cost then measured total factor productivity will be positively correlated with employment. Employment, however, is endogenous and would increase if there were an advance in technology, so Hall instruments employment with another variable--either the political party of the president, military spending, or the price of oil. Each fraction of Hall's audience would believe that at least one of these instruments is uncorrelated with shifts in technology, even though no fraction would believe that all of these instruments are.

Hall therefore uses a two step procedure to estimate the markup. First he calculates the change in total factor productivity in an industry--the Solow residual--in a given year using:

$$
\Delta(\mathrm{TFP})=\Delta\{\ln (\mathrm{VA} / \mathrm{K})\}-\alpha \Delta\{\ln (\mathrm{Hrs} / \mathrm{K})\}
$$

where TFP, VA, K, and Hrs are total factor productivity, value added, capital, and hours worked in the industry, and where $\alpha$ is labor's share of value added. Then Hall regresses the change in measured total factor productivity according to (1) on his instrument, and tests the hypothesis that the coefficient is zero.

Hall finds that for many industries measured total factor productivity is positively correlated with his instruments. In Hall (1988), however, the striking evidence of price in excess of marginal cost 
is provided almost exclusively by using the oil price as an instrument. The other instruments have little power.

\section{Constructing Value Added by Industry}

The Department of Commerce's Bureau of Economic Analysis constructs the National Income and Product Accounts' estimates of value added by industry used by Hall. For several industries, the procedures used by the BEA to calculate value added by industry make Hall's oil price instrument necessarily correlated with a spurious component in calculated value added. For these industries Hall's inferences, made under the assumption that the oil price instrument is appropriate, wilf not be valid.

Three different procedures are used by the Bureau of Economic Analysis to calculate value added by industry, depending on the availability of data. For most manufacturing industries the BEA uses a double deflation procedure. Nominal gross output in an industry is calculated from data on shipments and changes in inventories. Nominal intermediate inputs (materials and services consumed in production) are calculated by subtracting nominal factor incomes paid in the industry and additio charges such as taxes from nominal gross output. Separate price indices for the industry's final products and for its intermediate inputs are then used to calculate constant-dollar gross output and input measures. The important point for the purpose of this paper is that in the double-deflation procedure constant dollar intermediate inputs are actually measured, albeit indirectly. And the estimates of value added have no immediate bias.

The second procedure is a direct deflation method. The direct deflation procedure calculates constant-dollar value added by dividing nominal value added--factor payments in the industry--by a single price index. Typically, this price index is an index of the price of the industry's output. For example, in the trucking and warehousing industry constant-dollar value added is calculated by dividing nominal value added by an index of the price of trucking services: dollars charged per ton mile.

If the price of an input--such as gasoline--increases because of a rise in the price of oil, the 
direct-deflation method will create measurement errors negatively correlated with the price of oil as long as the ratio of price to marginal cost does not change and the production function is concave and exhibits constant returns to scale. An increase in the price of any input causes a less-than-proportional increase in marginal cost: under constant returns to scale, substitution away from a more costly input increases its marginal product; since marginal cost is equal to price divided by the marginal product of an input, an increase in the price of an input will cause a less-than-proportional increase in marginal cost. Assume--as Hall does--that there is no increase in the markup; then the percent increase in the price of final output is less than the percent increase in the price of the input.

Since the price of final output is just a weighted average of the value added deflator and the price of materials, an increase in the price of materials must cause a smaller percentage increase in the value added deflator than in the final output deflator. Therefore if nominal value added is deflated by the price of final output, the Bureau of Economic Analysis will record a spurious fall in real value added: deflation by the price of final output overcorrects for the increase in the value added deflator that follows an increase in materials prices. In other words, for those industries in which the direct deflation method is used, the BEA underestimated real value added during the years of upward oil price shocks. The real value added data thus contain measurement errors that are negatively correlated with the price of oil.

The third procedure used is an extrapolation procedure. For other industries, including the petroleum and coal industry; finance, insurance, and real estate; retail trade; and most services, the BEA does not estimate intermediate inputs but instead assumes that real value added is proportional to an indicator series such as employment or constant dollar gross output. (see Peterson, 1987).

Data on real value added constructed by this procedure will be of little value for Hall's purposes. If employment is the indicator series used, then labor productivity is assumed to be acyclic by construction. It thus becomes impossible to estimate the cyclical behavior of total factor productivity. If gross output is the indicator series used, estimates of value added are only valid if purchases of inputs are proportional to gross output--if the production function is Leontief. As the price of energy increases and firms substitute away from it by investing in energy efficient equipment, 
the BEA will neglect the reduction in purchased intermediate inputs and instead incorrectly calculate that value added per unit factor input has dropped. Again Hall's instrument, the change in the price of oil, will be negatively correlated with a spurious component of changes in reported real value added.

\section{The Construction of the Data Bias Estimated Markups Upward}

Reported value added in those industries for which the BEA uses direct deflation or extrapolation procedures to construct real value added estimates thus suffer from a measurement error negatively correlated with the change in the price of oil. Hall's estimates using the change in the price of oil as an instrument of the ratio of marginal cost to price $\beta$ will be biased downward. Hall calculates $\beta$ using equation 2 (Hall's equation 22):

$$
\beta=(\operatorname{cov}(\alpha \Delta \mathrm{n}, \Delta \mathrm{z})) /(\operatorname{cov}(\Delta \mathrm{q}, \Delta \mathrm{z}))
$$

where $\Delta \mathrm{q}$ is the percentage change in the ratio of real value added to capital, $\Delta \mathrm{n}$ is the percentage change in the labor/capital ratio, $\alpha$ is labor's share in value added, and $\Delta z$ is the instrument--in this the percentage change in the price of oil. Since an increase in the price of oil reduces production an employment, both the numerator and denominator of equation 2 are negative.

The denominator of equation 2 is biased down--away from zero--for those industries with data constructed by direct deflation or extrapolation. Therefore the estimate of $\beta$ is biased down, and the estimate of the markup $\mu=1 / \beta$ is biased up.

If other instruments used by Hall were also correlated with the price of materials inputs, estimates made using them would be biased as well. Since the oil shocks caused reduced growth in real GNP, real GNP would also be an invalid instrument and there would be an upward bias in the earlier estimates of the ratio of price to marginal cost published in Hall (1986).

The above arguments do not invalidate the results obtained with the two non-oil instruments used by in Hall (1988): military spending and the political party of the president. But using these instruments Hall rejects the hypothesis that price is equal to marginal cost at the five percent level less 
than six percent of the time--he rejects in only 3 of 52 regressions. The burden of the empirical results in Hall (1988) therefore rests on the validity of Hall's principal instrument, the change in the price of oil.

\section{EVIDENCE THAT DATA CONSTRUCTION LEADS TO BIASED ESTIMATES}

This section evaluates the severity of the bias introduced into Hall's estimates of the markup $\mu$ by the use of data constructed using direct deflation and extrapolation procedures in two steps. First, the results Hall (1988) presents for two digit industries are inspected. Second, direct tests of the validity of oil as an instrument using Hall's data set (kindly provided by Hall) are performed.

\section{Exploratory Data Analysis}

Table 1 reproduces Hall's table 3 and shows the probability, under the null hypothesis that perfect competition obtains and the true ratio of marginal cost to price is 1 , of estimating a ratio of marginal cost to price $\beta$ as low as that estimated by Hall. Marginal notes indicate the method used by the BEA to construct real value added, and the industries for which Hall rejects the null hypothesis that price equals marginal cost at the five percent level. For two of the two digit industries studied by Hallpetroleum and coal products, and retail trade--real value added is constructed by extrapolation from gross output. For two other industries--wholesale trade, and communication--real value added is estimated by direct deflation, using the price of sector output as the deflator. Finally, each of the three procedures is used for different sub-sectors of the transportation industry. For the remaining industries the double deflation procedure is used to construct value added.

Using the percent change in the price of oil as an instrument, Hall rejects the hypothesis that price equals marginal cost at the $5 \%$ level for nine industries. For the twenty-one industries in which real value added is calculated by double deflation, Hall rejects the null hypothesis for only five of twenty-one industries. Yet he rejects the null hypothesis for four out of five industries in which real value added is calculated by one of the other procedures. If a rejection of the hypothesis of perfect 
competition was equally likely in all all industries, the probability that four or more of nine rejections belong to a set of only five industries is only 0.03447 . Hall's results tend to be strongest when his data are untrustworthy.

It is, however, possible that the suspect industries are in fact less competitive than those industries for which real value added is constructed by double deflation. It is also possible that employment is more cyclical in the industries with suspect data, which would increase the power of Hall's test in those industries.

These questions can be addressed indirectly by examining the results reported for the other two instruments used by Hall (1988). Using military spending as an instrument, Hall rejects the null hypothesis that price equals marginal cost for two industries--one of which has suspect data. The probability that one or more of two randomly-selected industries possesses suspect datais over $35 \%$. Using the political party of the president as an instrument Hall rejects competition for only one industry, for which double deflation is used. The two non-oil instruments certainly do not strongly suggest that markups are higher or that employment is more procyclical in industries with suspect de.

\section{Ordinary Least Squares Tests}

The preliminary evidence that data problems are affecting Hall's estimates suggests that a more thorough analysis of the validity of the price of oil as an instrument is in order. ${ }^{1}$ I directly test the validity of Hall's oil price instrument by estimating:

(3) $\alpha \Delta \ln (\mathrm{N} / \mathrm{K})=\mathrm{c}+\beta \Delta \ln (\mathrm{Q} / \mathrm{K})+\gamma \Delta \ln ($ price of oil)

using ordinary least squares. If the change in the price of oil is a bad instrument for the suspect industries because of the procedures used to construct value added data, the underlying $\gamma$ will be positive. When the price of oil rises, true value added falls less than measured value added. Therefore employment falls less than would be expected given labor's share and the fall in measured value added. If the change in the price of oil is an appropriate instrument, then changes in the price of oil shift 
demand but are independent of measurement error in the change in value added and the change in employment. Accordingly, under the null that the change in the price of oil is an appropriate instrument the underlying $\gamma$ in equation 3 will be zero.

Hall (1988) seeks to produce unbiased estimates of the ratio of marginal cost to price $\beta$. He, therefore, must use instrumental variables since true technological change is correlated with his measured regression variables. ${ }^{2}$ The correlation of true technological progress in an industry with its value added biases $\beta$ downward.

If $\beta$ is underestimated, the effect on employment of an adverse demand shock is underestimated. Since oil price rises are correlated with falls in demand, an underestimated $\beta$ will make an oil price rise associated with a surprisingly large fall in employment given the drop in output, The estimated $\gamma$ will therefore be biased down in ordinary least squares estimates of equation 3 .

I aim to determine whether $\gamma$ is greater than zero, and to conclude if $\gamma$ is greater than zero that oil is a poor instrument. Thus the ordinary least squares estimate of $\gamma$ is biased against the alternative hypothesis that the underlying $\gamma$ is positive, and positive estimates of $\gamma$ are more significant rejections of the null hypothesis than appears at first glance. It is acceptable to estimate equation 3 using ordinary least squares to assess the appropriateness of the oil price instrument. 3

Ordinary least squares estimates of equation 3 strongly support the suspicion that the change in the price of oil is negatively correlated with measurement error in value added for those industries with suspect data. The coefficient on oil is positive for four of the five suspect industries. For petroleum and coal products, wholesale trade, and transportation the t-statistics are $2.623,2.695$, and 1.855 , rejecting the null hypothesis in favor of the one-sided alternative that the price of oil is negatively correlated with measurement error in real value added by industry. For the communication industry the coefficient on the change in the price of oil positive but not statistically significant. For retail trade the coefficient is not statistically significant and is negative.

In sharp contrast, none of the estimated $\gamma$ coefficients is significant and positive for any of the twenty-one industries where double deflation procedures are used to construct value added. For thirteen of these other industries, the coefficient on the change in the price of oil is negative--as would 
be expected given the analysis of the bias in ordinary least squares estimates of $\gamma$. Complete results are reported in table 2 .

The results from the different industry regressions can be summarized by taking the estimated t-statistics on the coefficient $\gamma$ of oil from the 26 industry regressions and regressing them on a constant and an indicator variable equal to one for industries that possess suspect data. The disturbance terms of this regression would be independent only if true technological change is uncorrelated in different industries. However, Hall (1986) has argued that this is in fact the case.

The summary regression also provides strong evidence that measurement error in the change in real value added is negatively correlated with the change in the price of oil. The t-statistic of the coefficient on oil is on average 1.486 higher for industries with suspect data. The t-statistic of the summary regression is 2.637 .4 Even if the petroleum and coal industry, the industry for which the bia caused by Hall's procedures is most evident and obvious, is excluded from the summary regression the t-statistic is 1.903 . Results from the cross industry summary regressions are reported in table 3 .

\section{Instrumental Variables Results}

It is desirable to determine if ordinary least squares results are consistent with the results of two stage least squares regressions like those reported in Hall (1988). I re-estimated equation 3 by two-stage least squares using Hall's instruments to address any concern that the conclusions reported above are driven by the use of ordinary least squares. The instruments used in the two-stage least squares regressions are a constant, the change in the price of oil, the change in defence spending, and the political party of the president.

Unfortunately, as the results using these instruments in Hall (1988) paper show, neither of theses instruments is strongly correlated with changes in real value added either. As a result my TSLS regressions generate first stage fitted values of the change in real value added which are nearly a constant times the change in the price of oil. As a result tests have little power, and these two stage least squares regressions cannot be expected to reject the null hypothesis that Hall's results are not

biased by the data construction procedure. ${ }^{4}$ Nevertheless it is important to see whether the point 
estimates are consistent with those generated by the ordinary least squares regressions.

Table 4 presents the coefficient on oil in the two stage least squares estimation of equation 3 using Hall's three instruments. For four of the five industries with suspect data the coefficient on the price of oil is positive, as would be expected if the price of oil is not a valid instrument. By contrast, there are only four positive estimated $\gamma$ coefficients among the twenty-one industries where real value added is calculated by double deflation.

Only one coefficient is statistically significant: the petroleum and coal industry, for which real value added is calculated by extrapolation from sales. The world price of oil clearly affects the Solow residual in this industry directly, and so Hall's assumption that the oil price affects the level of production but not the technology used is invalid in this case. For the communication and wholesale trade industries, for which real value added is calculated by direct deflation, the estimated $\gamma$ coefficient is positive but not statistically significant.

A summary regression using the reported t-statistics from instrumental variables estimation of the coefficient $\gamma$ on the oil price can also be used to pool the evidence for bias generated by the negative correlation between measurement error in value added and the change in the price of oil. The coefficient on the indicator variable is 1.08 , indicating that the $t$-statistic of the coefficient on oil was on average 1.08 higher in the industries with suspect data. The t-statistic of the summary regression was 3.06 , significant at the $0.269 \%$ level against the one sided alternative. When the petroleum and coal products industry was excluded from the regression, the coefficient fell to 0.683 and the t-statisticfell to 2.01 , significant at the $2.79 \%$ level against the one sided alternative hypothesis.

Since a constant was included, the above regression allows for the possibility that the underlying $\gamma$ was non-zero even in industries where real value added was calculated by double deflation. Alternatively, setting the constant equal to zero imposes the requirement that the true coefficient $\gamma$ of oil in these industries is zero. This regression gives a t-statistic of only 2.17 including the oil industry and of 0.997 excluding it. Complete results are shown in table 3.

This comparison of the two stage and ordinary least squares regressions eases the suspicion that the ordinary least squares estimates are biased for some addition reason. The standard method of 
testing for bias in an ordinary least squares regression would be the Hausman-Wu test. Such a test, however, would reject the null too often in a sample as small as the one studied here; in the HausmanWu test the asymptotic distribution is calculated assuming that the estimated standard error is the true standard deviation of the estimate.

Nevertheless, Hausman-Wu tests of the coefficient on oil do not reject the hypothesis that the ordinary least squares estimates of the coefficient on oil has the same expected value as the two stage least squares estimates. Table 3 also reports Hausman-Wu t-like statistics for the industries with suspect data calculated by:

$$
\text { statistic }=\left(\gamma_{\text {ols }}-\gamma_{\text {tsls }}\right) /\left(\left(\text { var }_{\text {tsls }}-\text { var }_{\text {ols }}\right)^{1 / 2}\right)
$$

The Hausman-Wu t-like statistics were also regressed on a the indicator variable with and without a constant. The coefficient on the indicator variable would then be likely to be positive if the results reported earlier were generated by bias in the ordinary least squares regressions. Instead, the point estimate is negative and insignificant with a constant included, and positive but not statisticall significant--with a t-statistic of 0.244 --with the constant excluded. The assertion that the ordinary leas squares results are unbiased is not rejected by the data.

\section{CONCLUSION}

The results reported in section III above confirm the theoretical presumption that the constructed data on real value added for five of the industries studied by Hall (1988) cannot be reliablyo used to estimate price cost margins. Measurement error in constructed real value added in these suspect industries is correlated with the only powerful instrument used by Hall. Measurement error is also presumably correlated with real GNP, the instrument used in Hall's earlier work on the same topic (Hall, 1986). These suspect data industries include four of the seven industries for which Hall reports the clearest rejection of perfect competition, and include four of the five non- manufacturing industries 
analyzed by Hall (1988).

These problems do not clearly invalidate earlier and subsequent research demonstrating noncompetitive pricing, such as Hall (1986), and Domowitz, Hubbard, and Petersen (1988). However, they do limit severely the range of industries for which Hall's procedure can be used to obtain reliable estimates of markups. The data problems, therefore, greatly hamper efforts to determine the causes of high markups by studying a wide sample of industries.

On the other hand, the method used to construct value added data accounts for the mysteriously high markups estimated by Hall for some non-manufacturing industries in which firms do not appear to possess large amounts of market power. One criticism of Hall (1988) has been that since the pattern of markups by industry reported is unbelievable there must be some hidden defect in his procedure. Since Hall's anomalous results can be accounted for by data problems which do not invalidate his general approach, the results of this note increase confidence in Hall's method and his general conclusions that price exceeds marginal cost in manufacturing. 


\section{NOTES}

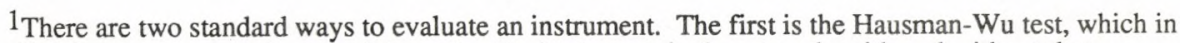
this case compares estimates of the ratio of price to marginal cost made with and without that instrument. The second is a simple T-test to determine if the instrument should be included as a right hand side variable in the instrumented equation.

Since Hall's data set includes only 33 yearly observations for each industry, a Hausman-Wu test can not be performed. This test depends on the asymptotic consistency of the estimated standard error of the two stage least squares coefficient. It is valid only for large samples. Since for some industries the estimated standard error of the estimate of the ratio of price to marginal cost is only very slightly lower when oil is included as an instrument, these industries report very high and implausible value of the Hausman-Wu statistic. Therefore, I concentrate on t-tests of the coefficient $\gamma$ on oil to decide whether it is a valid instrument.

2Ordinary least squares estimates of $\beta$ are biased down as long as output per unit of capital increasestin response to a favorable technological shock. In general let $\Delta \mathrm{z}$ be an index of the change in aggregate demand, and $\Delta \theta$ be the improvement in technology uncorrelated with the change in aggregate demand, and let $\Delta \mathrm{q}=\mathrm{A} \Delta \mathrm{z}+\mathrm{C} \Delta \theta, \alpha \Delta \mathrm{n}=\beta(\Delta \mathrm{q}-\Delta \theta)$. The ordinary least squares estimate b of the ratio of marginal cost to price will then be given by equation $\mathrm{A} 1$ :

$$
b=\beta\left[\frac{A^{2} \operatorname{var}(\Delta z)+C(C-1) \operatorname{var}(\Delta \theta)}{A^{2} \operatorname{var}(\Delta z)+C^{2} \operatorname{var}(\Delta \theta)}\right]
$$

The estimate of the ratio of marginal cost to price is biased down so long as $C$ is greater then zero. $\mathrm{C}$ is the elasticity of output with respect to a technological shock. Therefore ordinary least squares estimates of $\beta$ are biased down, as asserted, as long as output per unit of capital increases in response to a favorable technological shock.

${ }^{3}$ The first tests of oil as an instrument made were the two-stage least squares tests reported below; I then shifted to ordinary least squares estimates in search of greater power.

${ }^{4}$ This is the standard t-statistic as reported by RATS. Since, under the null hypothesis the variances of the t-statistics of the coefficients on oil are one, the standard error of the coefficient on the indicator variable could alternatively be calculated under the null assuming that the standard error of the disturbance is one. Since the estimated standard error is greater than one for each regression, this correction would give a higher t-statistic.

${ }^{4}$ The limited power of tests based on the instruments used in Hall (1988) also motivates the addition of another instrument. A natural addition is the change in real GNP, an instrument Hall used in his earlier $>$ work (see Hall, 1986). This instrument is correlated with the change in the price of oil: the oil shocks of the 1970's caused recessions. Nevertheless, it adds to the precision of the estimates of the coefficient $\gamma$ on oil. The bias due to the effect of oil shocks on GNP reduces the chance of finding a significant coefficient $\gamma$ on the change in the price of oil in the industries with suspect data.

When the change in real GNP is added to the instrument list to increase the power of the two 
stage least squares regressions, the results for individual industries are strengthened, but only slightly. The sign of the coefficient on oil for the transportation industry switches to the expected positive sign but the sign of the coefficient $\gamma$ for retail trade becomes negative. Each remains statistically insignificant. The results for the other industries with suspect data are virtually unchanged. The coefficients have the same sign and the t-statistics are slightly larger. Similarly, the results of the summary regressions are similar with and without GNP as an additional instrument (data not shown). 


\section{REFERENCES}

Domowitz, Ian; Hubbard, R. Glenn; and Petersen, Bruce (1988). "Market Structure and Cyclical Fluctuations in U.S. Manufacturing." Rev. Econ. and Statis. 70 (February): 55-66.

Hall, Robert E. (1988). "The Relation Between Price and Marginal Cost in U.S. Industry." Journal of Political Economy. 96, 5 (October): 921-947.

Hall, Robert E. (1986) "Market Structure and Macroeconomic Fluctuations." Brookings Papers on Economic Activity. 1986, 2 (Fall): 285-322.

Peterson, Milo (1987). "Gross Product by Industry, 1986." Survey of Current Business (April):22-27.

Solow, Robert M. (1957). "Technical Change and the Aggregate Production Function." Rev. Econ and Statis. 39 (August): 312-20. 
Table 2

Ordinary Least Squares Estimates

\begin{tabular}{|c|c|c|c|c|}
\hline \multicolumn{2}{|c|}{ Industry } & $\beta$ & $\gamma$ & $\begin{array}{l}\text { Durbin- } \\
\text { Watson }\end{array}$ \\
\hline 20 & Food and Kindred Products & $\begin{array}{c}.053 \\
(.069)\end{array}$ & $\begin{array}{l}-.014 \\
(.018)\end{array}$ & 1.05 \\
\hline 21 & Tobacco Manufactures & $\begin{array}{c}.014 \\
(.064)\end{array}$ & $\begin{array}{l}-.054 \\
(.028)\end{array}$ & 1.79 \\
\hline 22 & Textile Mill Products & $\begin{array}{c}.377 \\
(.076)\end{array}$ & $\begin{array}{l}-.026 \\
(.047)\end{array}$ & 2.44 \\
\hline 23 & Apparel and Other Textile Products & $\begin{array}{c}.720 \\
(.085)\end{array}$ & $\begin{array}{l}-.026 \\
(.034)\end{array}$ & 2.08 \\
\hline 24 & Lumber and Wood Products & $\begin{array}{c}.424 \\
(.092)\end{array}$ & $\begin{array}{l}-.075 \\
(.061)\end{array}$ & 1.96 \\
\hline 25 & Furniture and Fixtures & $\begin{array}{c}.585 \\
(.043)\end{array}$ & $\begin{array}{l}-.007 \\
(.054)\end{array}$ & 2.03 \\
\hline 26 & Paper and Allied Products & $\begin{array}{c}.281 \\
(.035)\end{array}$ & $\begin{array}{l}-.001 \\
(.022)\end{array}$ & 1.07 \\
\hline 27 & Printing and Publishing & $\begin{array}{c}.398 \\
(.066)\end{array}$ & $\begin{array}{c}.016 \\
(.019)\end{array}$ & 1.10 \\
\hline 28 & Chemicals and Allied Products & $\begin{array}{c}.157 \\
(.039)\end{array}$ & $\begin{array}{c}.028 \\
(.020)\end{array}$ & 1.67 \\
\hline 29 & Petroleum and Coal Products $(\mathrm{E})^{*}$ & $\begin{array}{c}.186 \\
(.079)\end{array}$ & $\begin{array}{c}.097 \\
(.037)\end{array}$ & 1.25 \\
\hline 30 & Rubber and Misc. Plastic Products & $\begin{array}{c}.609 \\
(.063)\end{array}$ & $\begin{array}{l}-.017 \\
(.042)\end{array}$ & 2.10 \\
\hline 31 & Leather and Leather Products & $\begin{array}{c}.492 \\
(.068)\end{array}$ & $\begin{array}{l}-.032 \\
(.040)\end{array}$ & 2.16 \\
\hline 32 & Stone, Clay, and Glass Products & $\begin{array}{c}.524 \\
(.040)\end{array}$ & $\begin{array}{c}.029 \\
(.022)\end{array}$ & 2.04 \\
\hline 33 & Primary Metals & $\begin{array}{c}.464 \\
(.032)\end{array}$ & $\begin{array}{c}.022 \\
(.031)\end{array}$ & 2.47 \\
\hline 34 & Fabricated Metal Products & $\begin{array}{c}.738 \\
(.069)\end{array}$ & $\begin{array}{c}.044 \\
(.093)\end{array}$ & 2.31 \\
\hline 35 & Machinery Except Electrical & $\begin{array}{c}.560 \\
(.060)\end{array}$ & $\begin{array}{c}.046 \\
(.042)\end{array}$ & 1.15 \\
\hline 36 & Electric and Electronic Equipment & $\begin{array}{c}.598 \\
(.065)\end{array}$ & $\begin{array}{c}.034 \\
(.039)\end{array}$ & 2.16 \\
\hline
\end{tabular}


Table 1

Marginal Significance Levels

\begin{tabular}{|c|c|c|c|}
\hline Industry & $\begin{array}{l}\text { Military } \\
\text { Spending }\end{array}$ & $\begin{array}{l}\text { Oil } \\
\text { Price }\end{array}$ & $\begin{array}{l}\text { Political } \\
\text { Party }\end{array}$ \\
\hline Food and Kindred Products & .398 & $.023^{*}$ & .265 \\
\hline Tobacco Manufactures & .087 & .231 & .366 \\
\hline Textile Mill Products & .253 & .082 & .170 \\
\hline Apparel and Other Textile Products & .208 & .614 & .591 \\
\hline Lumber and Wood Products & .632 & .250 & .096 \\
\hline Furniture and Fixtures & $.043 *$ & .063 & .447 \\
\hline Paper and Allied Products & .191 & $.004 *$ & .271 \\
\hline Printing and Publishing & .068 & .081 & .500 \\
\hline Chemicals and Allied Products & .184 & $.001^{*}$ & .291 \\
\hline Petroleum and Coal Products $(\mathrm{E})^{* *}$ & .053 & $.001 *$ & .425 \\
\hline Rubber and Misc. Plastic Products & .285 & .237 & .246 \\
\hline Leather and Leather Products & .141 & .494 & .161 \\
\hline Stone, Clay, and Glass Products & .357 & $.002 *$ & .370 \\
\hline Primary Metals & .155 & .341 & .221 \\
\hline Fabricated Metal Products & .265 & .092 & .304 \\
\hline Machinery Except Electrical & .748 & .063 & .624 \\
\hline Electric and Electronic Equipment & .252 & $.027 *$ & $.038^{*}$ \\
\hline 371 Motor Vehicles and Equipment & .369 & .124 & .376 \\
\hline 372-9 Other Transportation Equipment & .455 & .557 & .669 \\
\hline Instruments and Related Products & .478 & .723 & .362 \\
\hline Miscellaneous Manufacturing & .452 & .144 & .075 \\
\hline Communications (D) & .356 & .216 & .674 \\
\hline Electric, Gas, and Sanitary Services & .440 & .208 & .202 \\
\hline Transportation (M) & $.022^{*}$ & $.020 *$ & .219 \\
\hline Wholesale Trade (D) & .270 & $.002^{*}$ & .283 \\
\hline Retail Trade (E) & .319 & $.013^{*}$ & .596 \\
\hline
\end{tabular}

*Significant at the .05 level.

**(E) denotes an industry for which data are suspect and constructed using extrapolation.

(D) denotes an industry for which data are suspect and constructed using direct deflation.

(M) denotes an industry for which data are suspect and constructed using a mixture of methods.

Note: This table replicates Hall's table 22. It reports marginal significance levels for a one-tailed test of the hypothesis that the covariance of the Solow residual and the instrument is positive, where the sign of the instrument is normalized to make it covary positively with production. 
371 Motor Vehicles and Equipment

372-9 Other Transportation Equipment

38 Instruments and Related Products

39 Miscellaneous Manufacturing

48 Communications (D)

49 Electric, Gas, and Sanitary Services

Transportation (M)

Wholesale Trade (D)

Retail Trade (E)

\section{.286 \\ $(.060)$}

$-.174$

(.095)

.449

$-.042$

(.118)

(.076)

.538

(.087)

.039

(.044)

.160

(.046)

$-.047$

(.035)

.146

(.162)

.009

(.023)

.024

$(.060)$

.007

(.012)

.615

(.044)

.042

.346

(.089)

.049

(.018)

$$
.297
$$

(.063)
2.77

1.82

2.44

1.89

1.91

0.27

*(E) denotes an industry for which data are suspect and constructed using extrapolation.

(D) denotes an industry for which data are suspect and constructed using direct deflation.

(M) denotes an industry for which data are suspect and constructed using a mixture of methods.

Note: The dependent variable is $\alpha \Delta \mathrm{n}$, the share of labor times the percent change in hours; $\beta$ is the estimated coefficient on the percent change in value added, and $\gamma$ is the estimated coefficient on the percent change in the price of oil. OLS standard errors are in parentheses. 
Table 3

Regressions of T-Statistics on Suspect Data Indicator Variable

$\begin{array}{lcccccc}\begin{array}{l}\text { Dependent } \\ \text { Variable }\end{array} & \text { OLS T } & \text { OLS T } & \text { TSLS T } & \text { TSLS T } & \text { Wu Statistic } & \text { Wu Statistic } \\ \mathrm{R}^{2} & .2246 & .2086 & .2812 & .1356 & .0233 & .1763 \\ \mathrm{SEE} & 1.1323 & 1.1208 & .7084 & .7610 & .5084 & .5466 \\ \text { Constant } & -.1737 & & -.3407 & & .2457 & \\ & (.2471) & & (.1546) & & (.1109) & \\ \text { Indicator } & 1.4856 & 1.3119 & 1.0801 & 0.7393 & -.1913 & .0544 \\ \text { Variable } & (.5635) & (.5012) & (.3525) & (.3403) & (.2530) & (.2445) \\ \text { P-Value } & .0072 & .0074 & .0027 & .0197 & .7716 & .4129 \\ \text { Corrected } & .0032 & .0035 & .0204 & .0554 & .6480 & .4521 \\ \text { P-Value } & & & & & & \end{array}$

Note: The dependent variables are the T-statistics and T-like Wu statistics from the regressions reported in tables 2 and 4. The indicator variable takes on a value of one for petroleum and coal products, communication, transportagion, wholesale trade, and retail trade. All regressions use 26 industries. Corrected significance levels are calculated assuming that the true variance of the disturbances is one-the variance of the t-statistics under the null hypothesis that they have the t-distribution and are unrelated to the indicator variable. All significance levels are one-tailed, and $\amalg$ standard errors are in parentheses. 
Table 4

Two-Stage Least Squares Squares Estimates

Using Hall's Instruments

\begin{tabular}{|c|c|c|c|c|c|c|c|c|}
\hline \multicolumn{2}{|c|}{ Industry } & $\beta$ & $\gamma$ & $\begin{array}{l}\text { Significance } \\
\text { of } \gamma\end{array}$ & $\begin{array}{l}\text { Durbin- } \\
\text { Watson }\end{array}$ & $\begin{array}{l}\text { Hausman } \\
\text { Wu T- } \\
\text { Like } \\
\text { Statistic }\end{array}$ & $\begin{array}{l}\text { n- } \\
\text { Significance } \\
\text { of T-Like } \\
\text { Statistic }\end{array}$ & 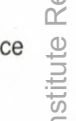 \\
\hline 20 & Food and Kindred Products & $\begin{array}{c}.287 \\
(.439)\end{array}$ & $\begin{array}{c}.013 \\
(.056)\end{array}$ & .412 & 1.479 & -.0495 & .688 & 5 \\
\hline 21 & Tobacco Manufactures & $\begin{array}{r}.079 \\
. .252\end{array}$ & $\begin{array}{l}-.061 \\
(.041)\end{array}$ & .926 & 1.896 & .2448 & .404 & 5 \\
\hline 22 & Textile Mill Products & $\begin{array}{l}.177 \\
(.316)\end{array}$ & $\begin{array}{l}-.070 \\
(.086)\end{array}$ & .790 & 2.562 & .6213 & .270 & \\
\hline 23 & Apparel and Other Textile Products & $\begin{array}{l}1.205 \\
(.753)\end{array}$ & $\begin{array}{l}-.001 \\
(.062)\end{array}$ & .507 & 1.920 & -.4701 & .679 & \\
\hline 24 & Lumber and Wood Products & $\begin{array}{l}-.137 \\
(.705)\end{array}$ & $\begin{array}{l}-.206 \\
(.185)\end{array}$ & .862 & 1.915 & .7476 & .230 & \\
\hline 25 & Furniture and Fixtures & $\begin{array}{c}.226 \\
(. .361)\end{array}$ & $\begin{array}{l}-.092 \\
(.107)\end{array}$ & .816 & 2.329 & .8967 & .189 & \\
\hline 26 & Paper and Allied Products & $\begin{array}{l}.165 \\
(.214)\end{array}$ & $\begin{array}{l}-.034 \\
(.066)\end{array}$ & .696 & 2.119 & .5410 & .296 & \\
\hline 27 & Printing and Publishing & $\begin{array}{c}.025 \\
(.442)\end{array}$ & $\begin{array}{l}-.005 \\
(.037)\end{array}$ & .558 & .985 & .6795 & .251 & \\
\hline 28 & Chemicals and Allied Products & $\begin{array}{c}.037 \\
(.205)\end{array}$ & $\begin{array}{l}-.004 \\
(.058)\end{array}$ & .526 & 1.853 & .5836 & .282 & \\
\hline 29 & Petroleum and Coal Products (E)* & $\begin{array}{l}.226 \\
(.148)\end{array}$ & $\begin{array}{l}.105 \\
(.045)\end{array}$ & .014 & 1.231 & -.3166 & .623 & \\
\hline 30 & Rubber and Misc. Plastic Products & $\begin{array}{c}-.062 \\
(2.075)\end{array}$ & $\begin{array}{l}-.121 \\
(.335)\end{array}$ & .640 & 2.349 & .3140 & .378 & \\
\hline 31 & Leather and Leather Products & $\begin{array}{c}.244 \\
(.496)\end{array}$ & $\begin{array}{l}-.048 \\
(.058)\end{array}$ & .795 & 2.338 & .3880 & .350 & \\
\hline 32 & Stone, Clay, and Glass Products & $\begin{array}{c}-.079 \\
(2.552)\end{array}$ & $\begin{array}{l}-.120 \\
(.643)\end{array}$ & .573 & 1.809 & .2314 & .409 & \\
\hline 33 & Primary Metals & $\begin{array}{c}.469 \\
(.102)\end{array}$ & $\begin{array}{l}-.022 \\
(.031)\end{array}$ & .759 & 2.478 & .0567 & .478 & \\
\hline 34 & Fabricated Metal Products & $\begin{array}{c}.291 \\
(1.502)\end{array}$ & $\begin{array}{l}-.130 \\
(.603)\end{array}$ & .585 & 2.449 & .2926 & .386 & \\
\hline 35 & Machinery Except Electrical & $\begin{array}{c}1.511 \\
(1.210)\end{array}$ & $\begin{array}{l}.175 \\
(.207)\end{array}$ & .203 & 1.489 & -.6371 & .736 & \\
\hline
\end{tabular}


36 Electric and Electronic Equipment

$$
\begin{array}{cc}
.222 & -.037 \\
(.297) & (.078)
\end{array}
$$

371 Motor Vehicles and Equipment

$$
.107-.280
$$$$
\text { (.959) (.573) }
$$

372-9 Other Transportation Equipment

$1.043 \quad-.012$

(.426) (.106)

38 Instruments and Related Products

39 Miscellaneous Manufacturing

48 Communications (D)

(2.085) (.047)

49 Electric, Gas, and Sanitary Services

Transportation (M)

Wholesale Trade (D)

Retail Trade (E)

$$
.039 \quad .039
$$

$.685 \quad .038$

(.534) (.046)

$$
\begin{array}{ll}
-.026 \quad-.086 \\
-.250) & (.067)
\end{array}
$$$$
\text { (250) }
$$

$.761 \quad .020$
0

$$
\begin{array}{cc}
.261 & .013 \\
(.442) & (.018)
\end{array}
$$

$$
.240 \quad-.004
$$$$
\text { (.257) (.052) }
$$

$$
2.674
$$$$
.0638
$$$$
.475
$$

.6780

.9830$$
\text { (..549) (.041) }
$$

1.032

.2731

$$
.449 \quad .003
$$$$
\text { (.395) (.043) }
$$

*(E) denotes an industry for which data are suspect and constructed using extrapolation.

(D) denotes an industry for which data are suspect and constructed using direct deflation.

(M) denotes an industry for which data are suspect and constructed using a mixture of methods

Note: See also the note to table 2 . The instruments used are military spending, the price of oil, and the political parts of the president. Standard errors are in parentheses. 


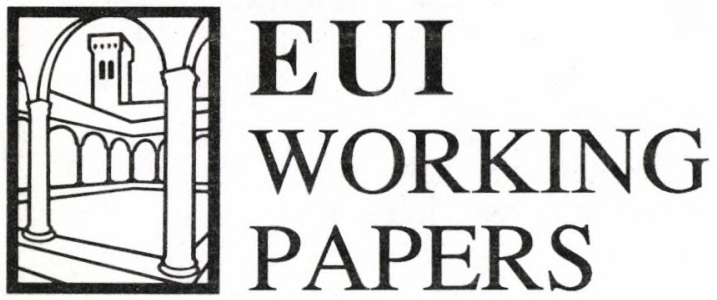

EUI Working Papers are published and distributed by the European University Institute, Florence

Copies can be obtained free of charge - depending on the availability of stocks - from:

The Publications Officer

European University Institute

Badia Fiesolana

I-50016 San Domenico di Fiesole (FI)

Italy

Please use order form overleaf 


\section{Publications of the European University Institute}

To The Publications Officer

European University Institute

Badia Fiesolana

I-50016 San Domenico di Fiesole (FI)

Italy

From Name

Address . . . . . . . . . . .

$\square$ Please send me a complete list of EUI Working Papers

$\square$ Please send me a complete list of EUI book publications

$\square$ Please send me the EUI brochure Academic Year 1990/91

Please send me the following EUI Working Paper(s):

No, Author

Title:

No, Author

Title:

No, Author

Title:

No, Author

Title:

Date

Signature 
$89 / 412$

Gianna GIANNELLI/

Gøsta ESPING-ANDERSEN

Labor Costs and Employment in

the Service Economy

\section{$89 / 413$}

Francisco S. TORRES

Portugal, the EMS and 1992:

Stabilization and Liberalization

\section{$89 / 414$}

Gøsta ESPING-ANDERSEN/

Harald SONNBERGER

The Demographics of Age in

Labor Market Management

\section{$89 / 415$}

Fritz von NORDHEIM NIELSEN

The Scandinavian Model:

Reformist Road to Socialism or

Dead End Street?

\section{$89 / 416$}

Joerg MAYER

Reserve Switches and Exchange-

Rate Variability: The Presumed

Inherent Instability of the Multiple

Reserve-Currency System

\section{$89 / 417$}

José P. ESPERANÇA/Neil KAY

Foreign Direct Investment and

Competition in the Advertising

Sector: The Italian Case

\section{$89 / 418$}

Luigi BRIGHI/Mario FORNI

Aggregation Across Agents in

Demand Systems

$89 / 419$

H. U. JESSURUN d'OLIVEIRA

Nationality and Apartheid:
Some Reflections on the Use of Nationality Law as a Weapon against Violation of Fundamental Rights

\section{$89 / 420$}

Corrado BENASSI

A Competitive Model of Credit Intermediation

$89 / 421$

\section{Ester STEVERS}

Telecommunications Regulation in the European Community: The Commission of the European

Communities as Regulatory Actor

$89 / 422$

Marcus MILLER/Mark SALMON

When does Coordination pay?

$89 / 423$

Marcus MILLER/Mark

SALMON/

Alan SUTHERLAND

Time Consistency, Discounting

and the Returns to Cooperation

$89 / 424$

Frank CRITCHLEY/Paul

MARRIOTT/Mark SALMON

On the Differential Geometry of the Wald Test with Nonlinear Restrictions

$89 / 425$

Peter J. HAMMOND

On the Impossibility of Perfect

Capital Markets

$89 / 426$

Peter J. HAMMOND

Perfected Option Markets in

Economies with Adverse Selection 
$89 / 427$

Peter J. HAMMOND

Irreducibility, Resource

Relatedness, and Survival with Individual Non-Convexities

\section{$89 / 428$}

Joanna GOYDER

"Business Format" Franchising and EEC Competition Law 


\section{Working Papers of the Department of Economics Published since 1989}

$89 / 370$

B. BENSAID/R.J. GARY-BOBO/

S. FEDERBUSCH

The Strategic Aspects of Profit Sharing in the Industry

\section{$89 / 374$}

Francisco S. TORRES

Small Countries and Exogenous Policy Shocks

$89 / 375$

Renzo DAVIDDI

Rouble Convertibility: A Realistic Target

\section{$89 / 377$}

Elettra AGLIARDI

On the Robustness of Contestability Theory

\section{$89 / 378$}

Stephen MARTIN

The Welfare Consequences of Transaction Costs in Financial Markets

\section{$89 / 381$}

Susan SENIOR NELLO

Recent Developments in Relations Between the $\mathrm{EC}$ and Eastem Europe

\section{$89 / 382$}

Jean GABSZEWICZ/ Paolo GARELLA/

Charles NOLLET

Spatial Price Competition With Uninformed Buyers

\section{$89 / 383$}

Benedetto GUI

Beneficiary and Dominant Roles in

Organizations: The Case of Nonprofits

\section{$89 / 384$}

Agustín MARAVALL/ Daniel PEÑA Missing Observations, Additive Outliers and Inverse Autocorrelation Function

\section{$89 / 385$}

Stephen MARTIN

Product Differentiation and Market Performance in Oligopoly

\section{$89 / 386$}

Dalia MARIN

Is the Export-Led Growth Hypothesis Valid for Industrialized Countries?
89/387

Stephen MARTIN

Modeling Oligopolistic Interaction

$89 / 388$

Jean-Claude CHOURAQUI

The Conduct of Monetary Policy: What have we Learned From Recent Experience

$89 / 390$

Corrado BENASSI

Imperfect Information and Financial Markets: A General Equilibrium Model

\section{$89 / 394$}

Serge-Christophe KOLM

Adequacy, Equity and Fundamental Dominance: Unanimous and Comparable Allocations in Rational Social Choice, with Applications to Marriage and Wages

$89 / 395$

Daniel HEYMANN/ Axel LEIJONHUFVUD

On the Use of Currency Reform in Inflation Stabilization

\section{$89 / 400$}

Robert J. GARY-BOBO

On the Existence of Equilibrium Configurations in a Class of Asymmetric Market Entry Games *

\section{$89 / 402$}

Stephen MARTIN

Direct Foreign Investment in The United States

$89 / 413$

Francisco S. TORRES

Portugal, the EMS and 1992: Stabilization and Liberalization

\section{$89 / 416$}

Joerg MAYER

Reserve Switches and Exchange-Rate Variability: The Presumed Inherent Instability of the Multiple Reserve-Currency System

$89 / 417$

José P. ESPERANÇA/ Neil KAY

Foreign Direct Investment and Competition in the Advertising Sector: The Italian Case 
$89 / 418$

Luigi BRIGHI/ Mario FORNI

Aggregation Across Agents in Demand Systems

$89 / 420$

Corrado BENASSI

A Competitive Model of Credit Intermediation

$89 / 422$

Marcus MILLER/Mark SALMON

When does Coordination pay?

$89 / 423$

Marcus MILLER/ Mark SALMON/

Alan SUTHERLAND

Time Consistency, Discounting and the Returns to Cooperation

\section{$89 / 424$}

Frank CRITCHLEY/ Paul MARRIOTT/

Mark SALMON

On the Differential Geometry of the Wald Test

with Nonlinear Restrictions

\section{$89 / 425$}

Peter J. HAMMOND

On the Impossibility of Perfect Capital Markets

\section{$89 / 426$}

Peter J. HAMMOND

Perfected Option Markets in Economies with Adverse Selection

\section{$89 / 427$}

Peter J. HAMMOND

Irreducibility, Resource Relatedness, and Survival with Individual Non-Convexities

ECO No. $90 / 1^{*}$

Tamer BAŞAR and Mark SALMON

Credibility and the Value of Information Transmission in a Model of Monetary Policy and Inflation

ECO No. 90/2

Horst UNGERER

The EMS - The First Ten Years

Policies - Developments - Evolution

ECO No. $90 / 3$

Peter J. HAMMOND

Interpersonal Comparisons of Utility: Why and how they are and should be made
ECO No. $90 / 4$

Peter J. HAMMOND

A Revelation Principle for (Boundedly) Bayesian Rationalizable Strategies

ECO No. $90 / 5$

Peter J. HAMMOND

Independence of Irrelevant Interpersonal Comparisons

ECO No. $90 / 6$

Hal R. VARIAN

A Solution to the Problem of Externalities and Public Goods when Agents are Well-Informed

ECO No. 90/7

Hal R. VARIAN

Sequential Provision of Public Goods

ECO No. $90 / 8$

T. BRIANZA, L. PHLIPS and J.F. RICHARD Futures Markets, Speculation and Monopoly Pricing

ECO No. $90 / 9$

Anthony B. ATKINSON/ John

MICKLEWRIGHT

Unemployment Compensation and Labour Market Transition: A Critical Review

ECO No. $90 / 10$

Peter J. HAMMOND

The Role of Information in Economics

ECO No. 90/11

Nicos M. CHRISTODOULAKIS

Debt Dynamics in a Small Open Economy

ECO No. 90/12

Stephen C. SMITH

On the Economic Rationale for Codetermination Law

ECO No. 90/13

Elettra AGLIARDI

Learning by Doing and Market Structures

ECO No. 90/14

Peter J. HAMMOND

Intertemporal Objectives

ECO No. 90/15

Andrew EVANS/Stephen MARTIN

Socially Acceptable Distortion of Competition: EC Policy on State Aid 
ECO No. $90 / 16$

Stephen MARTIN

Fringe Size and Cartel Stability

ECO No. 90/17

John MICKLEWRIGHT

Why Do Less Than a Quarter of the

Unemployed in Britain Receive Unemployment Insurance?

ECO No. 90/18

Mrudula A. PATEL

Optimal Life Cycle Saving

With Borrowing Constraints:

A Graphical Solution

ECO No. $90 / 19$

Peter J. HAMMOND

Money Metric Measures of Individual and Social

Welfare Allowing for Environmental

Externalities

ECO No. $90 / 20$

Louis PHLIPS/

Ronald M. HARSTAD

Oligopolistic Manipulation of Spot Markets and

the Timing of Futures Market Speculation

ECO No. 90/21

Christian DUSTMANN

Earnings Adjustment of Temporary Migrants

ECO No. $90 / 22$

John MICKLEWRIGHT

The Reform of Unemployment Compensation:

Choices for East and West

ECO No. $90 / 23$

Joerg MAYER

U. S. Dollar and Deutschmark as Reserve Assets

ECO No. $90 / 24$

Sheila MARNIE

Labour Market Reform in the USSR:

Fact or Fiction?

ECO No. $90 / 25$

Peter JENSEN/

Niels WESTERGÅRD-NIELSEN

Temporary Layoffs and the Duration of

Unemployment: An Empirical Analysis

ECO No. $90 / 26$

Stephan L. KALB

Market-Led Approaches to European Monetary

Union in the Light of a Legal Restrictions

Theory of Money
ECO No. 90/27

Robert J. WALDMANN

Implausible Results or Implausible Data?

Anomalies in the Construction of Value Added

Data and Implications for Estimates of Price-

Cost Markups

ECO No. $90 / 28$

Stephen MARTIN

Periodic Model Changes in Oligopoly

ECO No. $90 / 29$

Nicos CHRISTODOULAKIS/

Martin WEALE

Imperfect Competition in an Open Economy 


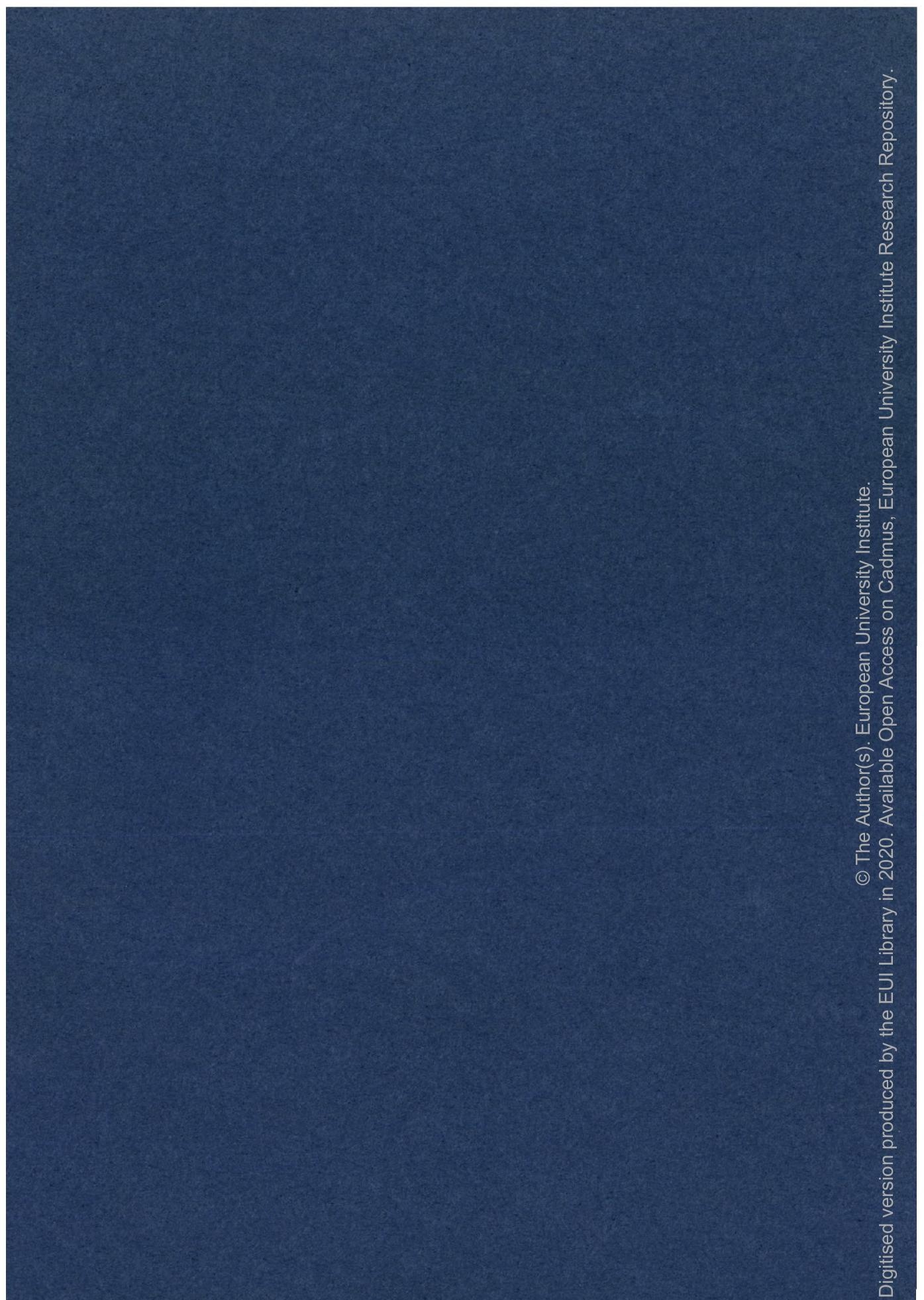




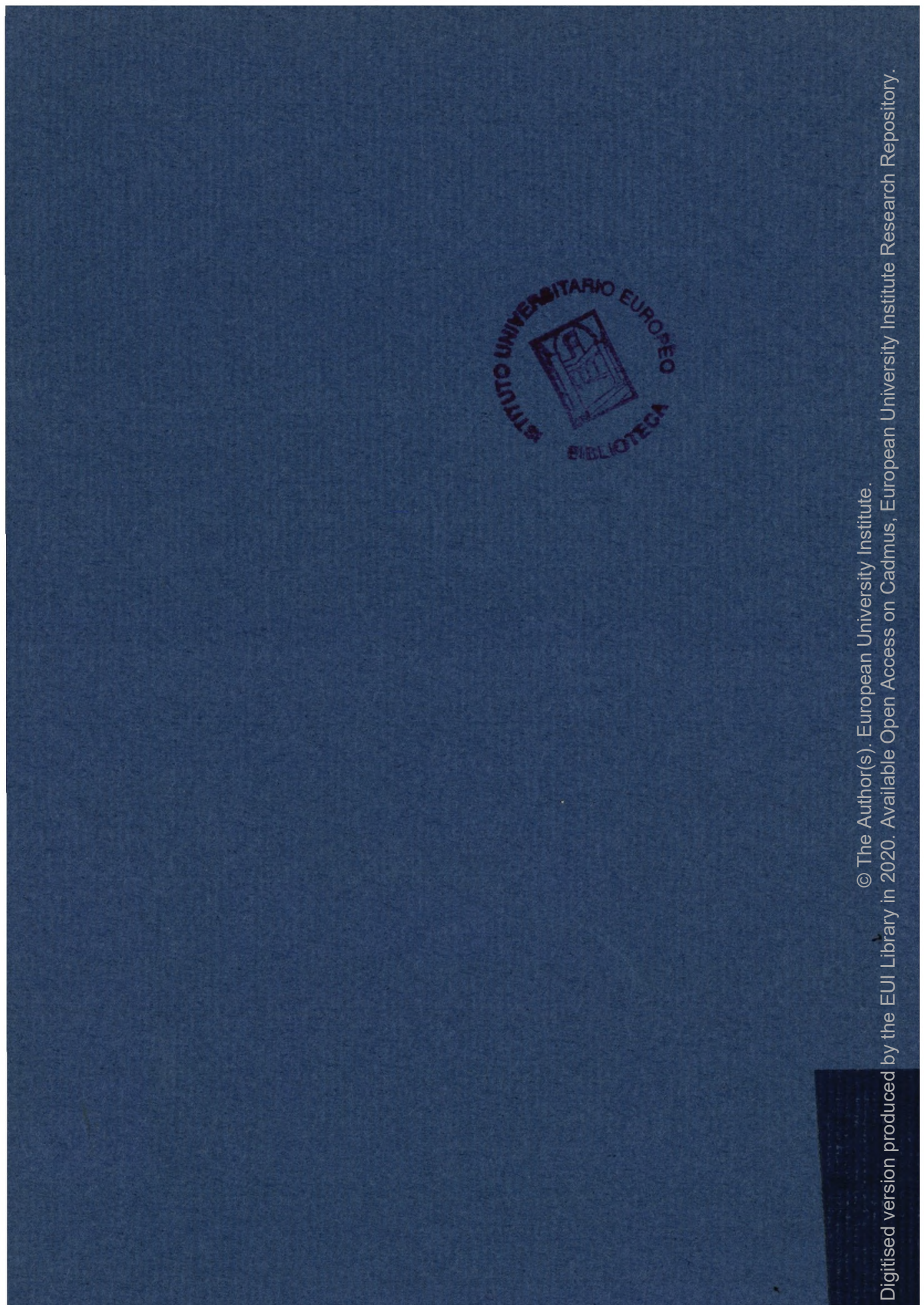

